\title{
Transcriptional and functional complexity of Shank3 provides a molecular framework to understand the phenotypic heterogeneity of SHANK3 causing autism and Shank3 mutant mice
}

Xiaoming Wang ${ }^{1}$, Qiong $\mathrm{Xu}^{1,3}$, Alexandra L Bey ${ }^{2}$, Yoonji Lee ${ }^{1}$ and Yong-hui Jiang ${ }^{1,2^{*}}$

\begin{abstract}
Background: Considerable clinical heterogeneity has been well documented amongst individuals with autism spectrum disorders (ASD). However, little is known about the biological mechanisms underlying phenotypic diversity. Genetic studies have established a strong causal relationship between ASD and molecular defects in the SHANK3 gene. Individuals with various defects of SHANK3 display considerable clinical heterogeneity. Different lines of Shank3 mutant mice with deletions of different portions of coding exons have been reported recently. Variable synaptic and behavioral phenotypes have been reported in these mice, which makes the interpretations for these data complicated without the full knowledge of the complexity of the Shank3 transcript structure.
\end{abstract}

Methods: We systematically examined alternative splicing and isoform-specific expression of Shank3 across different brain regions and developmental stages by regular RT-PCR, quantitative real time RT-PCR (q-PCR), and western blot. With these techniques, we also investigated the effects of neuronal activity and epigenetic modulation on alternative splicing and isoform-specific expression of Shank3. We explored the localization and influence on dendritic spine development of different Shank3 isoforms in cultured hippocampal neurons by cellular imaging.

Results: The Shank3 gene displayed an extensive array of mRNA and protein isoforms resulting from the combination of multiple intragenic promoters and extensive alternative splicing of coding exons in the mouse brain. The isoform-specific expression and alternative splicing of Shank3 were brain-region/cell-type specific, developmentally regulated, activity-dependent, and involved epigenetic regulation. Different subcellular distribution and differential effects on dendritic spine morphology were observed for different Shank3 isoforms.

Conclusions: Our results indicate a complex transcriptional regulation of Shank3 in mouse brains. Our analysis of select Shank3 isoforms in cultured neurons suggests that different Shank3 isoforms have distinct functions.

Therefore, the different types of SHANK3 mutations found in patients with ASD and different exonic deletions of Shank3 in mutant mice are predicted to disrupt selective isoforms and result in distinct dysfunctions at the synapse with possible differential effects on behavior. Our comprehensive data on Shank3 transcriptional regulation thus provides an essential molecular framework to understand the phenotypic diversity in SHANK3 causing ASD and Shank3 mutant mice.

Keywords: Activity-dependent gene regulation, Alternative splicing, Autism spectrum disorder, Phenotypic heterogeneity, Shank3 isoform

\footnotetext{
* Correspondence: yong-hui.jiang@duke.edu

'Division of Medical Genetics, Department of Pediatrics, Duke University

School of Medicine, 27710 Durham, NC, USA

2Department of Neurobiology, Duke University School of Medicine, 27710

Durham, NC, USA

Full list of author information is available at the end of the article
}

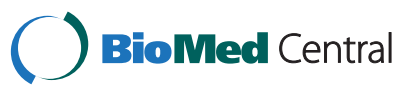

(c) 2014 Wang et al.; licensee BioMed Central Ltd. This is an Open Access article distributed under the terms of the Creative Commons Attribution License (http://creativecommons.org/licenses/by/2.0), which permits unrestricted use, distribution, and reproduction in any medium, provided the original work is properly credited. The Creative Commons Public Domain Dedication waiver (http://creativecommons.org/publicdomain/zero/1.0/) applies to the data made available in this article, unless otherwise stated. 


\section{Background}

Shank3/ProSAP2 is one of three members of the Shank/ProSAP family of proteins which contain five conserved protein domains - an ankyrin repeat (ANK), a Src homology 3 (SH3), a PSD-95/Discs large/ZO-1 (PDZ), a proline-rich region containing homer- and cortactin-binding sites (Pro), and a sterile alpha motif (SAM) [1-3]. Shank proteins localize in the postsynaptic density (PSD) of excitatory synapses where they function as master scaffolding proteins by interacting directly or indirectly with various proteins, including major types of glutamate receptors - NMDARs, AMPARs, and mGluRs via different domains [1,2,4-8].

Human genetic studies strongly support the notion that molecular defects of SHANK3 contribute to autism spectrum disorders (ASD). In humans, SHANK3 maps to the critical region of the 22q13.3 deletion syndrome (Phelan-McDermid syndrome; PMS), in which autistic behaviors are an important feature [9]. In addition, de novo sequence variants including missense, frame-shift, and splice site mutations across all coding exons of SHANK3 have been identified in $\sim 0.5 \%$ of ASD patients with variable clinical presentations [10-14]. Interestingly, SHANK3 mutations were also reported in patients with childhood-onset schizophrenia and intellectual disability [15]. In the cases with point mutations or small deletions of $S H A N K 3$, it was noted that clinical features are also quite variable [8]. Shank3 mutant mice with deletions of exons encoding ANK, SH3, and PDZ domains and proline-rich region have been reported [16-20]. These mutant mice shared some similarities but also have significant differences in synaptic defects and behavioral abnormalities. The interpretations for the data from different lines of mutant mice were complicated at the time by the lack of clear understanding of the complexity of Shank3 transcript structure. It was believed that different lines of mutant mice only disrupted a select set of Shank3 isoforms. These observations then demand more knowledge of transcriptional regulation of Shank3 in the brain, and pose an interesting question about the molecular basis underlying the clinical heterogeneity in human patients with SHANK3 defects and the variability in different Shank3 mutant mice.

SHANK3 undergoes complex transcriptional regulation [8,21-24]. We and others have determined that Shank3 displays multiple intragenic promoters and alternative splicing of coding exons in both mice and humans $[12,18,23,25,26]$. The combination of multiple promoters and alternative splicing is predicted to produce an extensive array of mRNA and protein isoforms, but this has not been fully characterized. With the information of presumptive SHANK3 isoforms, point mutations or small exonic deletions of SHANK3 found in ASD patients are predicted to affect selective isoforms of $S H A N K 3$. Since each SHANK3 isoform contains a distinct combination of the five different protein-protein interaction domains, each isoform may have a different function at the synapse. One interesting hypothesis is that isoform-specific disruptions by point mutations and small intragenic deletions within the SHANK3 gene contribute to the clinical heterogeneity in humans and variable phenotypes seen in mice.

As a first step to test this hypothesis, we conducted a series of experiments to systematically characterize the extent and regulation of isoform-specific expression of Shank3 in mice because of the ready availability of brain tissues and amenability of this model species to experimental manipulation. We discovered that Shank3 undergoes extensive alternative splicing in the exons encoding for conserved protein domains. We report, for the first time, that the expression and alternative splicing of Shank3 isoforms are brain-region and developmentally specific, activity dependent, and involve epigenetic regulation. We also found that different Shank3 isoforms displayed different subcellular distribution and differential effects on dendritic spine morphology, suggesting a different function for each isoform. We propose that isoform diversity of Shank3 is one of the explanations for the phenotypic diversity in humans and mice carrying various Shank3 defects.

\section{Methods}

\section{Animals}

All experiments in animals were conducted with approved protocols by the Institutional Animal Care and Use Committee at Duke University.

\section{Primary neuron culture and drug treatments}

The methods for primary hippocampal and cortical neuron cultures were described previously [18]. Briefly, hippocampal and cortical tissues were dissected from newborn C57BL/6J pups between postnatal day 0 and day 1 , and digested with trypsin. Tissues were pelleted by brief centrifugation and then dissociated in Neurobasal/ B27 medium. Cells were plated into $60 \mathrm{~mm}$ dishes coated with $0.1 \mathrm{mg} / \mathrm{mL}$ poly-D-lysine at a density of $4 \times 10^{6}$ cells/ dish. Cells were treated on 8-10 days in vitro with either $30 \mathrm{mM} \mathrm{KCl}$ or $5 \mu \mathrm{M}$ trichostatin A (TSA) for 16 hours. Astrocyte monolayers were derived from the hippocampus of postnatal day 7 C57BL/6J mice as described [27]. Total RNA and protein were prepared for quantitative PCR or western blot analysis.

\section{DNA constructs and transfection}

Mouse brain cDNAs were prepared from cerebral cortex of 8-week-old mice. Specific primers for Shank3 isoforms $(3 a, 3 b, 3 c$, and $3 e)$ were employed to amplify PCR products containing the complete open reading frame of each isoform, and the PCR products were cloned into EGFP-C1 
vectors using In-Fusion Cloning Kits (Clontech, CA, USA). COS-7 cells growing on coverslips in 6-well plates were transfected with $2 \mu \mathrm{g}$ of different Shank3 constructs using FuGENE HD transfection reagent (Promega, WI, USA) according to the manufacturer's technical manual. The cells were fixed by $4 \%$ paraformaldehyde 36 hours post-transfection. Dissociated hippocampal neurons were grown on poly-D-lysine-coated coverslips. After 7 days in vitro, neurons were transfected with Shank3 constructs using Lipofectamine 2000 transfection reagent (Invitrogen, CA, USA). Briefly, on the day of transfection, half of the medium was removed from each well and kept at $4^{\circ} \mathrm{C}$. DNA and Lipofectamine 2000 were mixed in serum-free neurobasal medium with a ratio $1: 3(\mu \mathrm{g}: \mu \mathrm{L})$. The mixture was added into each well and incubated for 6 hours before replacement with the previously saved conditioned medium. The cells were fixed by $4 \%$ paraformaldehyde after 14 days in vitro. To analyze the spine morphology, neurons were co-transfected with Shank3 constructs and a tdTomato plasmid.

\section{Immunochemistry and morphology analysis of dendritic spines}

Fixed neurons were permeabilized with $0.2 \%$ triton-X 100 in $1 \times$ phosphate buffered saline (PBS), blocked with $2 \%$ bovine serum albumin, and co-stained with rabbit antiGFP (Invitrogen) and mouse anti-PSD-95 (UC Davis/NIH NeuroMab Facility) antibodies and corresponding secondary antibodies conjugated with Alexa 488 or Alexa 568. Confocal images were obtained using a $63 \times$ objective (Zeiss LSM 510 inverted) with sequential acquisition settings of $1024 \times 1024$ pixels. Each image was a z-series projection of 3-4 images at $0.5-\mu \mathrm{m}$ depth intervals and averaged four times. Morphometric analysis and quantification of PSD-95 and dendritic spines were performed using Image J software (NIH, Bethesda, MD, USA) by an experimenter who was blinded to experiment conditions.

\section{RNA isolation and RT-PCR expression analysis}

Tissues from different brain regions were dissected from coronal sections of brain slices cut by a Leica VT 1000p microtome (Leica, IL, USA). Total RNA was isolated using the TRIzol method (Life Technologies, CA, USA). Reverse transcription was performed with SuperScript ${ }^{\oplus}$ III firststrand synthesis system (Invitrogen). Real-time quantitative RT-PCR (q-PCR) was carried out using a LightCycler 480 Instrument (Roche Diagnostics, Mannheim, Germany) and QuantiFast SYBR green PCR kit (Qiagen, CA, USA), following the manufacturer's recommendations. The primers used in this study are listed in Additional file 1: Table S1. AccuPrime GC-Rich DNA Polymerase (Invitrogen) was employed to amplify the full-length GC-rich sequence of exons 10-12 of Shank3. The sequences of newly identified splice variants were annotated and deposited in
Genbank. Quantification of the bands of splicing variants were carried out using Image J [28].

\section{Western blot}

Western blot was performed as previously described [29]. Briefly, brain tissues were homogenized and sonicated in modified RIPA buffer ( $1 \times$ PBS, $1 \%$ Triton X-100, 0.1\% SDS, $2 \mathrm{mM}$ EDTA, and protease inhibitors); $25 \mu \mathrm{g}$ of proteins were resolved by PAGE and transferred onto polyvinylidene difluoride (PVDF) membranes. The PVDF membranes were blocked with $5 \%$ milk and incubated with Shank3 (1:5,000 in 5\% non-fat milk) antibody (sc-30193, Santa Cruz, Dallas, TX, USA) at $4^{\circ} \mathrm{C}$ overnight. Following incubation with horseradish peroxidaseconjugated secondary antibody, the membranes were incubated with a Pierce chemiluminescent substrate (Rockford, IL, USA) and exposed to X-ray film.

\section{Results}

\section{Multiple protein isoforms produced by intragenic} promoters in mouse brain

The mouse Shank3 gene has 22 exons that encode a synaptic scaffolding protein with five functional domains (Figure 1A). We have previously demonstrated that the Shank3 gene contains at least five intragenic promoters in humans and rodents which produce promoter-specific isoforms of Shank3 with various combinations of different functional domains $[8,18,25]$ as summarized in Figure 1E. The presence of multiple intragenic promoters is supported by CHIP sequencing data from the ENCODE project (Additional file 2: Figure S1B, http://genomebrowser.wustl.edu). The analysis of ENCODE data also suggests that these intragenic promoters are brain specific, which was confirmed by western blot analysis of Shank3 protein among different tissues (Additional file 2: Figure S1C). The presence of intragenic promoters in vivo is also supported by the expression analysis in a list of Shank3 isoform-specific mutant mice. In these mutant mice, different portions of Shank3 exons were deleted, resulting in disruption of select sets of Shank3 proteins and mRNAs [16-20]. In support of these findings, Shank3 complete knockout mice with deletion of exons 4-22 showed absence of all known promoterspecific isoforms (data not shown).

\section{Extensive alternative splicing of Shank3 mRNAs confers further complexity to Shank3 isoforms}

Alternative splicing of Shank3 has been suggested [12,18] but has not been fully characterized. We conducted RTPCR with primer combinations that cover all exons of Shank3 (Additional file 2: Figure S1A) using total RNA from the cerebral cortex of 8 -week-old mice. We discovered that the coding exons 10-12, exon 18, exon 21, and exon 22 of Shank3 displayed extensive alternative splicing 


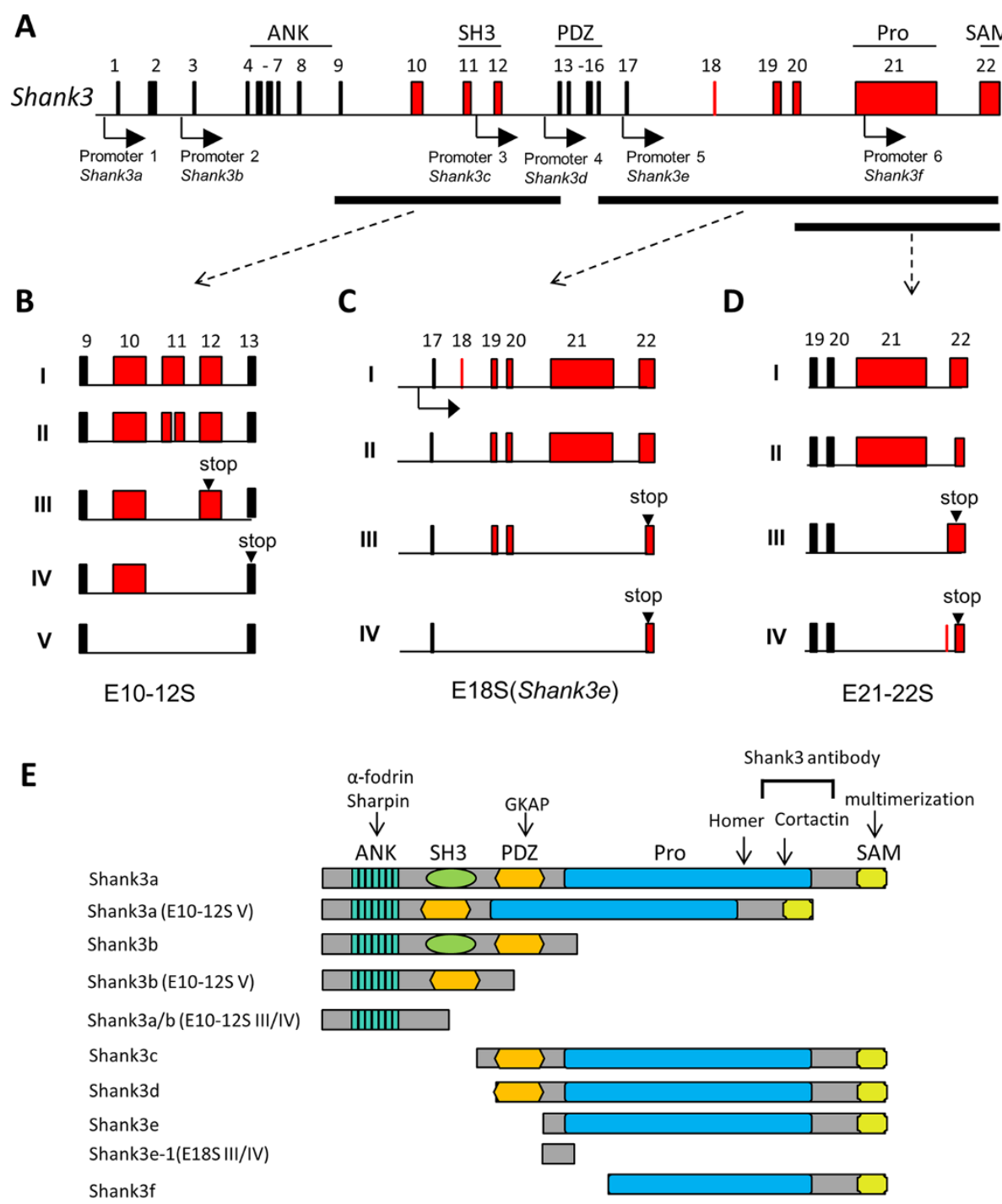

Figure 1 Diverse Shank3 isoforms result from intragenic promoters and alternative splicing. (A) Multiple promoters of the Shank3 gene. Mouse Shank3 has 22 coding exons as illustrated. The exon-intron structure was deduced by cDNA AB231013 in mm10 mouse genome assembly (www.genome.ucsc.edu). The alternatively spliced exons are highlighted in red. The positions of intragenic promoters are shown as black arrows. Protein domains encoded by exons are labeled above the gene structure. (B-D) Extensive alternative splicing of Shank3 coding exons. (B) Shank3 exons 10-12 splice variants (E10-12S I to V). The pattern was deduced from the sequences of PCR products in Figure S2A (Additional file 3). I: no splicing. II: exon 11 partially spliced out. III: exon 11 spliced out. IV: exons 11 to 12 spliced out. V: exons 10 to 12 spliced out. (C) Shank3e splice variants (E18S I to V). The pattern was deduced from the sequences of PCR products in Figure S2C (Additional file 3). I: no splicing. II: exon 18 spliced out. III: exons 18, 21, and 22 (partial) spliced out. IV: exons 18 to 21 and 22 (partial) spliced out. (D) Shank3 exon 21 and exon 22 splice variants (E21-22S I to IV). The pattern was deduced from the sequences of PCR products in Figure S2E (Additional file 3). I: no splicing. II: exon 22 (partial) spliced out. III: exon 21 spliced out. IV: exon 21 and exon 22 (partial) spliced out. (E) The predicted Shank3 protein isoforms were deduced from the combination of intragenic promoters and alternative splicing of mRNAs described above and in silico analysis. The binding positions of several well-known PSD proteins are shown by arrows. The epitope position for the Shank3 antibody used in this study is also indicated.

(Additional file 3: Figure S2). Interestingly, the alternatively spliced exons were concentrated in the conserved $\mathrm{SH} 3$, proline-rich, and SAM domains of Shank3 and resulted in protein species with different combinations of the five functional domains. The alterative splicing of exons 10-12 resulted in five different splice variants (E10-12S I to V, Figure 1B). E10-12S I represented the full length of this portion of mRNA without alternative splicing. In E10-12S II, a cryptic splicing of 57 nucleotides occurred in exon 11 without a shift of the open reading frame (ORF) of Shank3 mRNA. However, splice variants of E10-12S III and IV resulted in truncated isoforms only containing the ANK domain due to a frame shift of the Shank3 ORF (Figure 1E). Interestingly, skipping of exons 10 to 12 in E10-12S V was predicted to produce a Shank3 isoform without the $\mathrm{SH} 3$ domain but presumably retaining 
the other four protein domains (Figure 1E). Alternative splicing of exons 18-22 was examined by primers specific to promoter 5 for Shank3e (Additional file 2: Figure S1A). Four splice variants (E18S I to IV, Figure 1C) were identified. Exon 18 was spliced out in E18S II to IV. The splicing of exon 18 appeared to be in concert with splicing of exons 21/22 or exons 19-22 in Shank3 E18S III and IV, respectively. The frame shift of the Shank3 ORF in E18S III and IV variants is predicted to result in premature stop codons in exon 22 and produced short Shank3e isoforms (Shank3e-1) lacking the proline-rich region and SAM domain (Figure 1E). With a different set of primers, alternative splicing of exons 21 and 22 was examined, and four different variants were observed (E21-22S I to IV, Figure 1D). While the E21-22S I and II variants did not change the ORF of Shank3, the E21-22S III and IV variants were predicted to produce C-terminal truncated Shank3 isoforms lacking the SAM domain due to premature stop codons in exon 22. In summary, these results indicate that Shank3 undergoes extensive alternative splicing, which results in extreme diversity of Shank3 isoforms at mRNA and possibly at protein levels.

\section{Region- and development-specific expression of Shank3 isoforms in mouse brain}

Regional and developmental expression of Shank3 has been previously examined by RNA in situ hybridization $[17,30]$. However, the probes used in these studies could not distinguish between different Shank3 isoforms. To examine the isoform-specific expression of Shank3 in different brain regions, we performed isoform-specific q-PCR using 8-week-old mice (Figure 2A-E). Shank3a and Shank3e were highly expressed in striatum but low in olfactory bulb and cerebellum. In contrast, Shank3c and Shank3d were predominantly enriched in cerebellum. Shank $3 b$, an isoform without exon 21 encoding the homer binding site, is expressed at low levels throughout the brain. We were not able to design primers to examine mRNA from Shank3f because this promoter is embedded within exon 21 . Western blot analysis using an antibody against the C-terminus of Shank3 revealed an expression pattern that is highly correlated with the pattern of q-PCR (Figure 2F). Specifically, Shank3a and Shank3e were predominant in striatum and Shank3c/d was exclusively enriched in the cerebellum. Parenthetically, the diversity of Shank3 protein products may be under-represented because some truncated Shank3 protein isoforms are not detectable due to the location of the epitope of the Shank3 antibody used. Developmental expression of Shank3 was also examined by q-PCR using whole brains from mice of different ages (Figure 2G-K), and all isoforms showed an increase from postnatal day 1 to 4 weeks. The peak of expression was between 2 and 4 weeks, correlating with the time frame for synaptogenesis.
Shank3a and Shank3e displayed a gradual decrease after 4 weeks and reduced to $50 \%$ of the peak level at 12 months of age. In contrast, the expression of Shank3c and Shank3d was relatively stable throughout adulthood. Western blot revealed a similar pattern of Shank3 protein isoforms at different postnatal ages in mouse brain (Figure 2L). The temporally and spatially specific expression of Shank3 isoforms suggests different functions for different isoforms.

\section{Region-, development-, and cell-type-specific alternative splicing of Shank3 isoforms in mouse brain}

We next investigated whether alternative splicing of Shank3 isoforms also displays a temporally and spatially specific pattern in mouse brains. In the adult brain, the splicing of E10-12S III to IV showed a higher rate in the olfactory bulb and thalamus as compared to other regions (Figure 3A, B). The splicing of E18S II variants displayed a similar pattern (Figure 3A, C). During development, the splice variants E10-12S III and E18S II were prominent at postnatal day 1 , then rapidly decreased at postnatal day 5 and only expressed at marginal levels after postnatal day 10 (Figure 3D, E). The ratio of exon 18- (E18S II) versus exon 18+ (E18S I) was inverted from postnatal day 1 to postnatal day 5 (Figure 3F). The expression of E10-12S V significantly increased toward 4 weeks and decreased in the adult brain (Figure 3D). The splice variants of E18S III and IV were also differentially regulated during development. In addition, alternative splicing of Shank3 isoforms also displayed a cell-type-specific pattern (Additional file 4: Figure S3). Interestingly, alternative splicing of exon 18 was mutually exclusive between cell types, with exon 18 inclusion (E18S I) in neurons and exon18 exclusion (E18S II) in astrocytes. Similarly, the E18S III variant was exclusively observed in neurons while E18S IV was only found in astrocytes. Taken together, these results showed that alternative splicing of Shank3 is region-, development-, and cell-type-specific.

\section{Activity dependent expression and alterative splicing of Shank3}

The expression of many neuronal genes is regulated by neuronal activity [31,32]. To investigate if the splicing and expression of Shank3 are also regulated by neuronal activity, we treated cultured hippocampal neurons with $\mathrm{KCl}$. At the mRNA level, the expression of Shank3a, 3c, $3 d$, and $3 e$ in stimulated neurons was reduced to $40 \%$ to $70 \%$ of controls while the expression of Shank $3 b$ was not affected (Figure 4A). Similarly, Shank3 protein isoforms were markedly reduced after $\mathrm{KCl}$ treatment $(\sim 20 \%$ of controls) (Figure 4B, C). The reduction of Shank3 protein after $\mathrm{KCl}$ treatment was more pronounced than that of Shank3 mRNAs. The reason underlying the difference between the mRNAs and proteins was not immediately 

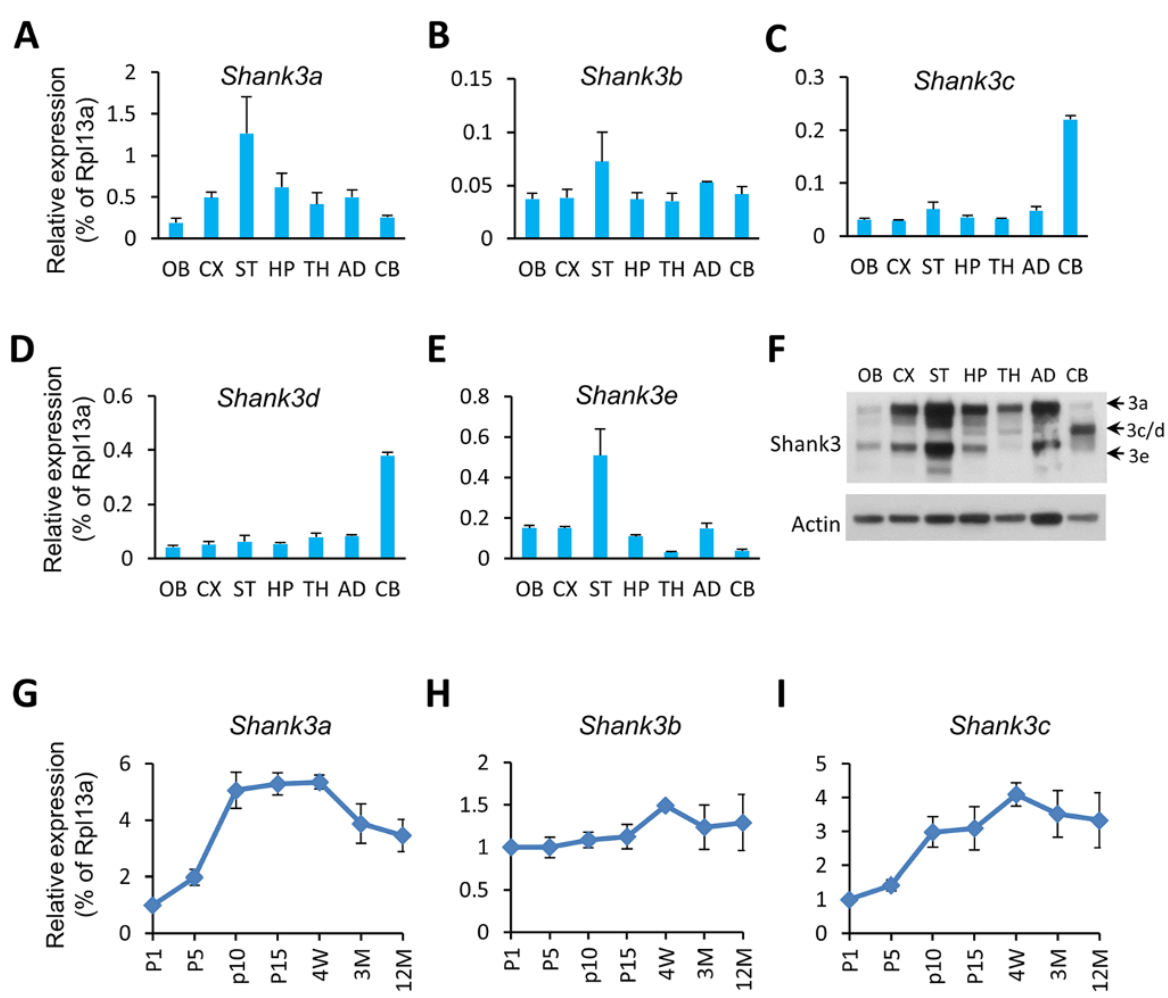

H

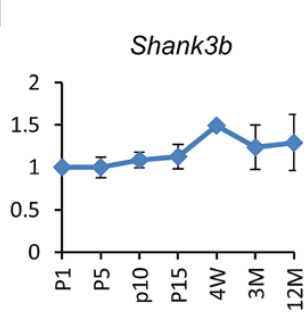

I

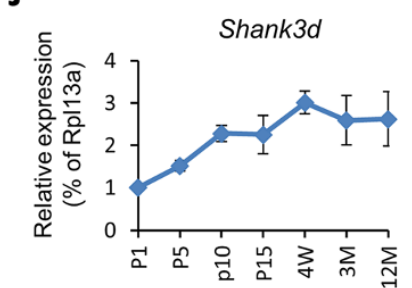

K
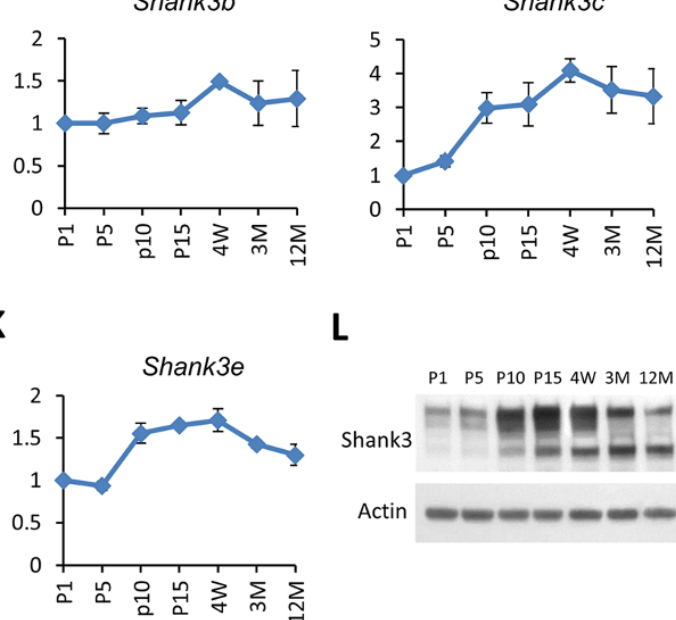

$\mathbf{L}$

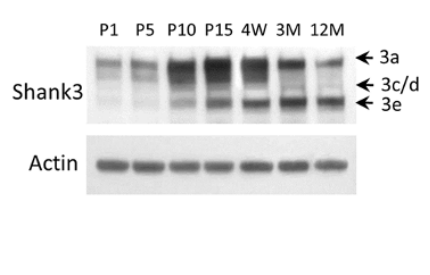

Figure 2 Differential expression of Shank3 isoforms across brain regions and development. (A-E) q-PCR of Shank3 major isoforms in different brain regions. (G-K) q-PCR of Shank3 isoforms in brain across development. The crossing point (CP) values of each isoform were normalized to that of a housekeeping gene, Rp/13a. For brain regions: OB, olfactory bulb; CX, cortex; ST, striatum; HP, hippocampus; TH, thalamus; $A D$, amygdala; $C B$, cerebellum. For different ages: P1, postnatal day 1; P5, postnatal day 5; P10, postnatal day 10; P15, postnatal day 15; 4 W, 4 weeks; 3 M, 3 months; 12 M, 12 months. (F and $\mathbf{L}$ ) Western blot analysis using an antibody produced from an epitope at the C-terminus of SHANK3 protein (amino acids 1431 to 1590) for different mouse brain regions (F) or at different ages (L). The predicted bands for Shank3a (185KD), Shank3c/d (128KD/127KD), and Shank3e (118KD) are indicated by arrows. All of these bands migrate a little higher than prediction, which may be caused by post-translational modifications of Shank3 proteins. Shank3b was not detectable as the epitope of the antibody was spliced out in this isoform. All data are shown as mean \pm SEM.

clear. Possibilities involving post-translational regulation of Shank3 protein may be considered. For example, ubiquitin/proteasome-mediated protein degradation of Shank family proteins following neuronal activity has been observed [31]. Alternative splicing of Shank3 was also affected by $\mathrm{KCl}$ treatment (Figure 4D). A significant increase in the splice variants E10-12S III to IV, E18S II, and E18S IV was observed after $\mathrm{KCl}$ treatment (Figure $4 \mathrm{E}-\mathrm{G}$ ). In contrast, the splice variants E21-22S were not affected (data not shown). These results indicate that the expression and alternative splicing of Shank3 isoforms are regulated by neuronal activity.

\section{Expression and alternative splicing of Shank3 are} regulated by a histone deacetylase (HDAC) inhibitor

Epigenetic modifications, such as histone acetylation, have been shown to regulate expression and alternative splicing of neuronal genes [33,34]. To examine whether expression and alternative splicing of Shank3 are subject to epigenetic regulation, we treated hippocampal neurons with TSA, a potent HDAC inhibitor. Interestingly, TSA treatment exerted differential effects on the isoform-specific expression of Shank3. At the mRNA level, Shank3a and Shank3e were significantly reduced while Shank3c and Shank3d were markedly increased (Figure 5A). The expression of 

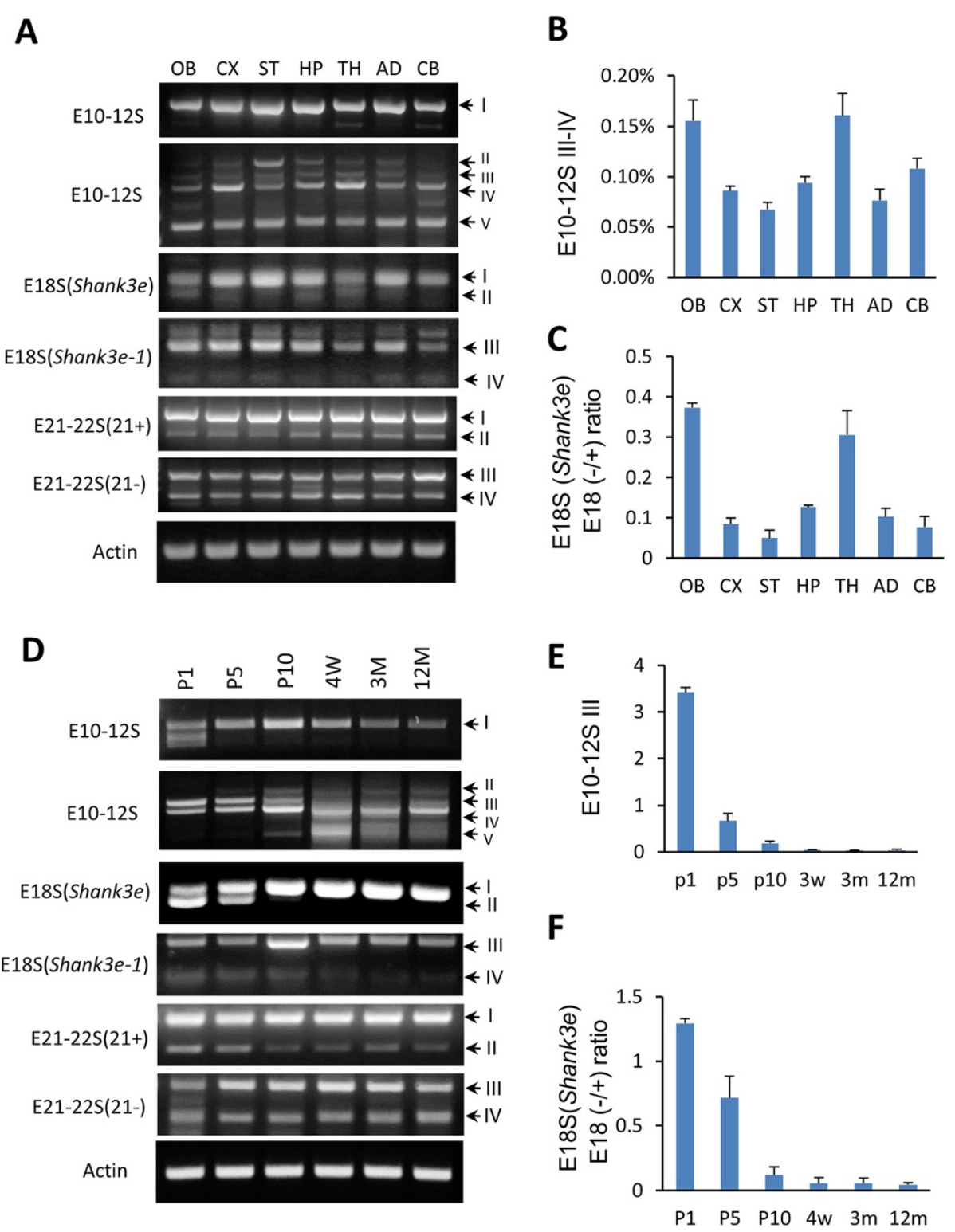

Figure 3 Alternative splicing of Shank3 in different brain regions and across development. (A) Splicing of Shank3 coding exons in different brain regions. (B) Quantification for splicing of E10-12S III to IV in (A). The values of the spliced bands were normalized to E10-12S I without splicing. (C) Quantification for splicing of exon 18 in (A). Values were shown as the ratio of exon18 (-) to exon18 (+). (D) Splicing of Shank3 coding exons during brain development. (E) Quantification for splicing of E10-12S III in (D), values of the spliced products were normalized to that of E10-12S I without splicing. (F) Quantification for splicing of exon 18 of Shank3e in (D). All data are shown as mean \pm SEM. The abbreviations for different brain regions and ages are the same as in Figure 2.

Shank3b was not affected. Reduced Shank3 expression was also supported by the overall reduction of Shank3 proteins (Figure 5B, C). However, isoform-specific changes were not apparent by western blot analysis. The discrepancy between the mRNA and protein expression is not immediately clear. The possibility of antibody specificity and sensitivity may be considered. Alternatively, the involvement of protein modification for different protein isoforms related to HDACs may also be a factor. TSA treatment also induced an increase in E10-12S III to IV and a reduction of E18S IV (Figure 5D, E, G). Splicing of E18S II was not changed despite a marked decrease of Shank3e mRNA (Figure 5D, F). Alternative splicing of Shank3 E21-22 was not affected by TSA treatment (data not shown). Taken together, the expression and splicing of Shank3 isoforms were differentially regulated by an HDAC inhibitor, suggesting the involvement of epigenetic modifications in regulating Shank3 expression, but the exact mechanisms are not immediately clear and further investigation is warranted. 


\section{A}

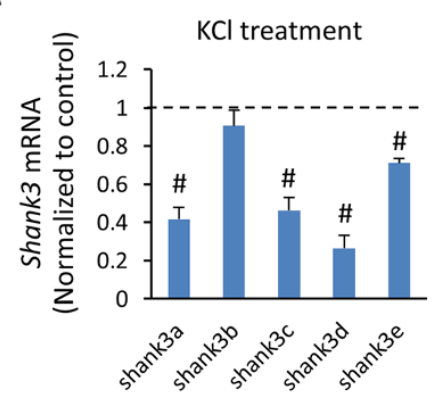

D

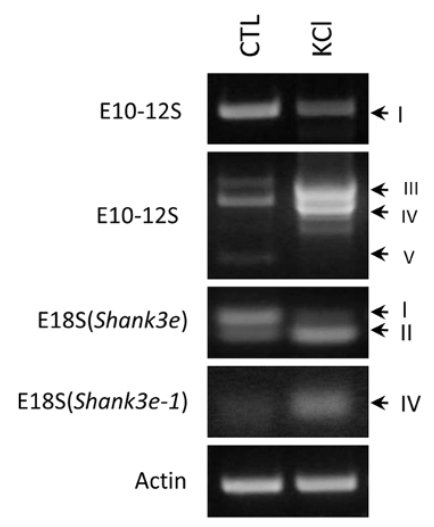

B

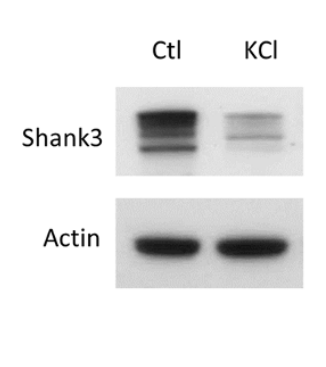

E

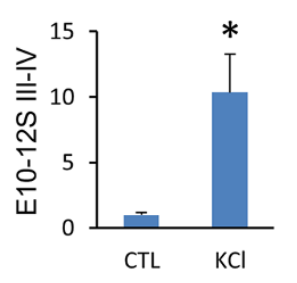

G

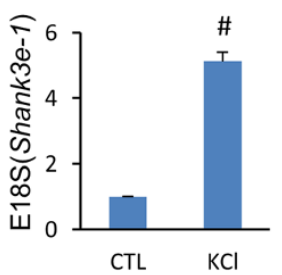

C

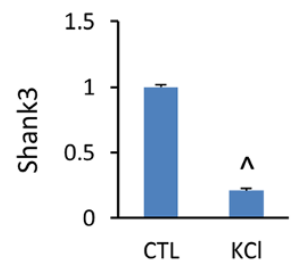

$\mathbf{F}$

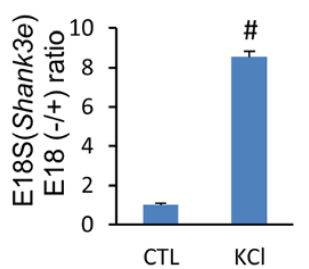

Figure 4 Neuronal activity-dependent isoform-specific expression and alternative splicing of Shank3. (A) q-PCR analysis of Shank3 isoforms in cultured mouse cortical neurons after treatment with $30 \mathrm{mM} \mathrm{KCl}$ for 18 hours. The expression of Shank3a, 3c, 3d, and 3e was significantly reduced while no change was observed for Shank3b. (B) Western blot showed reduced Shank3 proteins after $\mathrm{KCl}$ treatment. (C) Quantification for Shank3 proteins in (B). (D) Splicing of Shank3 isoforms after KCl treatment. Alternative splicing for E10-12S III-IV (E), E18S II of Shank3e (F), and E18S IV of Shank3e-1 (G) were increased after KCl treatment. All data are shown as mean \pm SEM. ${ }^{*} P<0.05$, \#P<0.002, $\wedge P<0.001$, compared to control group, two tail $t$-test, $n=4$ each group.

\section{Differential subcellular localization of Shank3 isoforms and their effects on dendritic spines}

To analyze the subcellular distribution of Shank3 isoforms and their roles in regulation of dendritic spines, we cloned cDNAs of major Shank3 isoforms into EGFP$\mathrm{C} 1$ vectors. First, we overexpressed these constructs in COS-7 cells (Additional file 5: Figure S4A). As a control, GFP showed a diffuse pattern without cluster formation, while Shank3a, c, and e, all containing the proline-rich region and SAM domain, formed clusters in the cytoplasm. Overexpression of Shank3 exon 22 only encoding the SAM domain displayed a similar pattern, indicating the clusters were mediated by the SAM domain through homo-/hetero-polymerization [1]. Interestingly, Shank3b was localized in the nucleus as it overlapped with DAPI, a nucleus-staining marker. This suggests that the lack of proline-rich and SAM domains may be responsible for its nuclear targeting. The nuclear localization of Shank3b was also verified when it was expressed in cultured hippocampal neurons (Additional file 5: Figure S4B). To determine whether any Shank3 isoform is present in inhibitory synapses or not, we examined the overlap of Shank3 isoforms with gephyrin, an inhibitory post-synaptic marker. None of the Shank3 isoforms examined localized in inhibitory synapses of cultured neurons (Additional file 6: Figure S5). However, it remains to be investigated whether the same is true in vivo in mouse brain due to the technical caveats of cultured cells. The co-localization of PSD-95, a marker of excitatory post-synapses, with Shank3a and Shank3c was observed in dissociated hippocampal neurons but was not apparent with Shank3b and Shank3e (Figure 6A). The size and the density of PSD-95 puncta were increased in Shank3a transfected neurons, indicating an increase in excitatory synapses. On the contrary, overexpression of Shank3b and Shank3e resulted in a reduction of the size and density of PSD-95 (Figure 6B, C). We further examined the contribution of different Shank3 isoforms in dendritic spine development by co-transfection of Shank3 isoforms and tdTomato in hippocampal neurons (Figure 6D). Shank3a and Shank3c caused an 
A

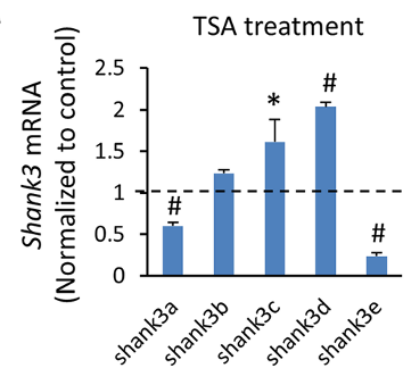

D

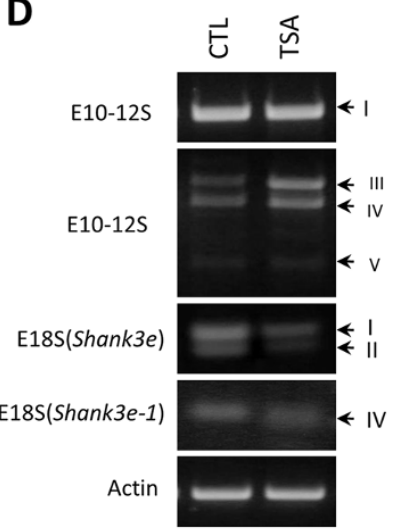

B

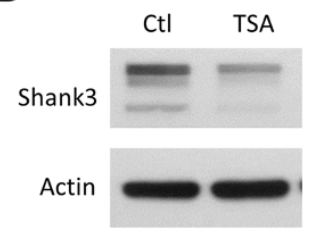

E

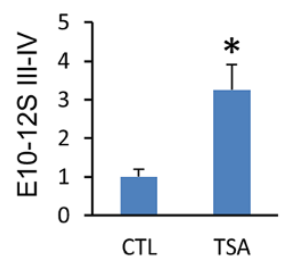

G

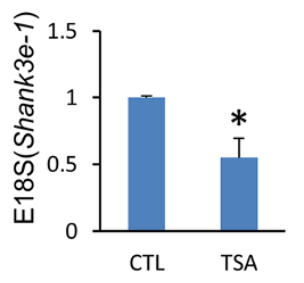

C

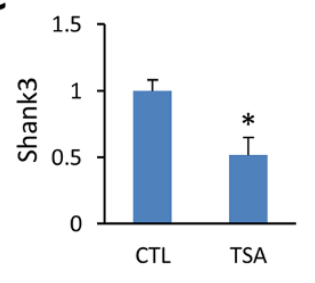

$\mathbf{F}$

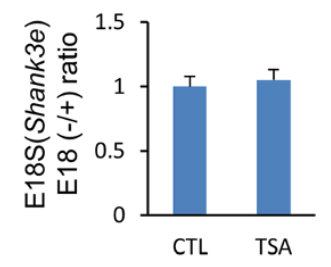

Figure 5 Differential isoform-specific expression and alternative splicing of Shank3 induced by a histone deacetylase (HDAC) inhibitor. (A) q-PCR analysis of Shank3 isoforms in cultured mouse cortical neurons after treatment with $5 \mu \mathrm{M}$ trichostatin A (TSA), a potent HDAC inhibitor, for 18 hours. (B) Western blot showed reduced Shank3 proteins after TSA treatment. (C) Quantification for Shank3 proteins in (B). (D) Differential changes of alternative splicing of Shank3 after TSA treatment. (E) Alternative splicing for Shank3 E10-12S III to IV was increased. (F) Splicing for E18S II of Shank3e was not changed. (G) Splicing for E18S IV of Shank3e-1 was decreased. All data are shown as mean \pm SEM. * $P<0.05$, \# $P<0.002$, compared to the control group, two tail $t$-test, $\mathrm{n}=4$ each group.

increase in spine density and a slight decrease in spine length compared to the EGFP control. Shank3b and Shank3e did not cause significant changes in the spine density $(P=0.47$ and 0.97 , respectively) but resulted in a marked increase in spine length (Figure 6E, F), indicating the formation of more immature synapses. These results indicate that Shank3 isoforms have different subcellular localization and differential effects on dendritic spine development, further suggesting that they play different roles in the brain.

\section{Discussion}

Using various molecular genetics approaches, we have described an unusually complex transcriptional profile for Shank3, a strong human autism causative gene, in the mouse brain. We have delineated transcript structures for major Shank3 isoforms resulting from the combination of multiple intragenic promoters and alternative splicing. Furthermore, we showed, for the first time, that the isoformspecific expression of Shank3 is temporally and spatially specific and regulated by neural activity. We showed that the isoform-specific expression of Shank3 in cortical neurons involves an epigenetic regulation suggested in previous reports $[23,35]$. Further, this is the first report indicating that a selective Shank3 isoform is strictly localized in neuronal nuclei which implies a novel function other than as a scaffolding protein at the PSD. Our results support the hypothesis that different Shank3 isoforms have distinct functions at synapses. These findings will promote our knowledge of the molecular diversity in the brain and help us to understand the phenotypic heterogeneity caused by various SHANK3 defects in humans and mice.

The implication of molecular complexity of Shank3 to the functional diversity of synapses

Our results reveal that Shank3 displays more isoforms in the brain than it does in peripheral tissues and suggest that each Shank3 isoform has a unique function, which allows us to propose that the complexity of Shank3 contributes to the functional diversity of synapses. First, the major isoforms of Shank3 generated from different promoters contain distinct combinations of the five conserved domains, which provide the functional diversity for Shank3 isoforms. The full-length Shank3a contains all five domains which would have the capacity to interact with all possible interacting proteins. Other isoforms 


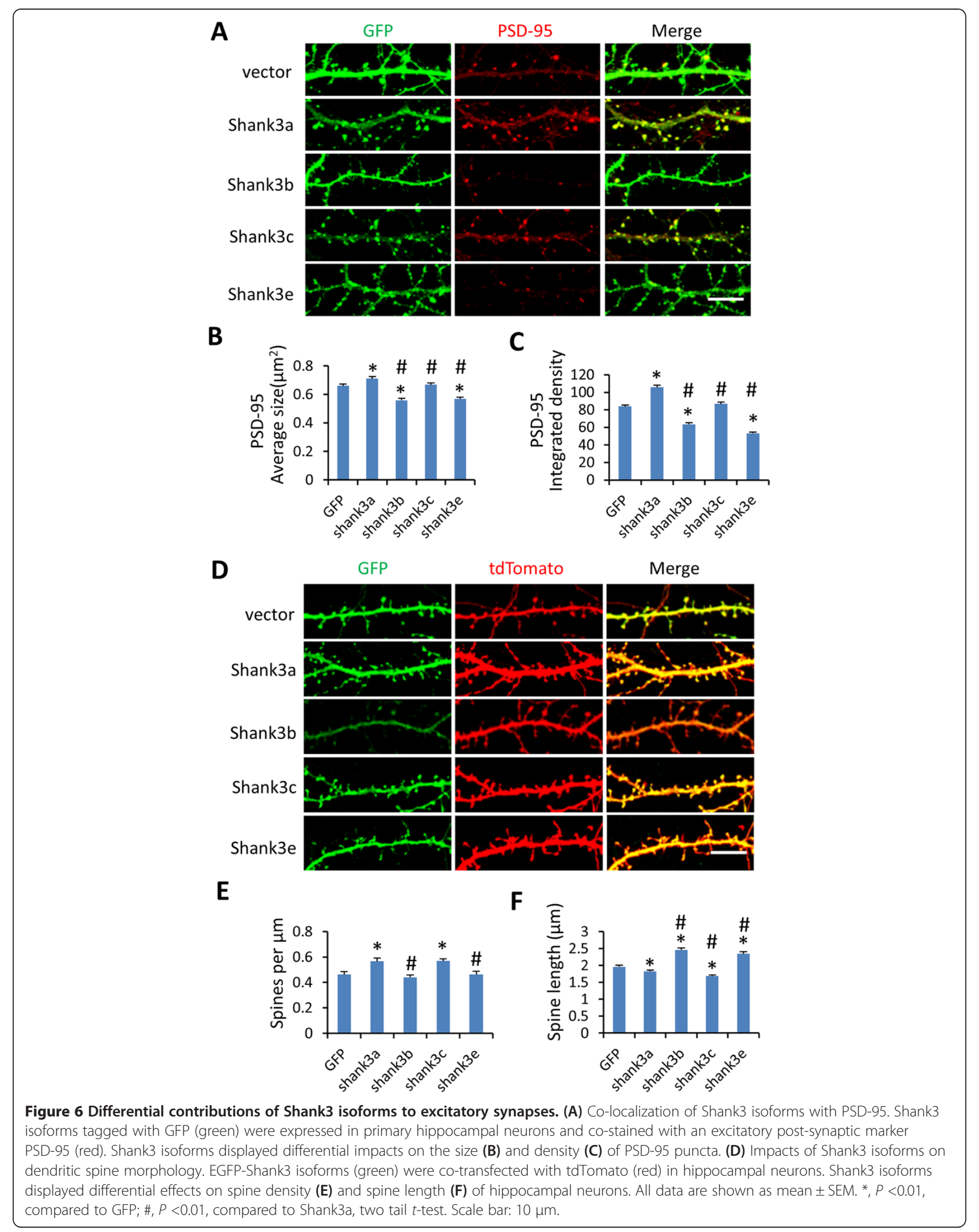


with different combinations of functional domains would then interact with a different subset of synaptic proteins. For instance, the N-terminal truncated Shank3e only contains the proline-rich region and SAM domain and would be able to couple with homer-mGluRs complexes but not GKAP-PSD95-NMDARs complexes [4,5]. In contrast, the C-terminal truncated Shank3b would be able to interact with NMDARs but not mGluRs. By competing with Shank3a, one of the functions of Shank3b and Shank3e might be the regulation of the cross-talk between NMDARs and mGluRs, which results in the fine tuning of synaptic transmission. Second, alternative splicing contributes to further complexity of Shank3 isoforms and functional diversity. Alterative splicing of Shank3 is predicted to have an impact on the function of Shank3 since it is heavily concentrated in the exons encoding functional protein domains. The splice variants of E10-12S III and IV generate truncated Shank3 isoforms which only contain the ANK domain known to interact with cytoskeleton proteins such as alpha-fodrin and sharpin [30,36]. Conceptually, these isoforms will compete with the binding of full-length Shank3 to alpha-fodrin and sharpin, thereby modulating the rearrangement of the PSD structure. It is interesting that these isoforms are highly expressed at early stages of brain development and concentrated in the olfactory bulb of adult brain. The splicing variant E18S II showed similar region- and development-specific splicing patterns to that of E10-12S, implying that they may coordinate with each other for some functions. Exon 18 inclusion may be considered a neuronal marker at the mRNA level, as it occurs specifically in neurons, but not in astrocytes or peripheral tissues [12]. Exon 18 contains 24 nucleotides that encode 8 amino acids containing an arginine stretch (RRRK) residues that is similar to the "RXR" motif. It has been shown that the RXR motif serves as an endoplasmic reticulum (ER) retention signal in the NMDA receptor subunit NR1 [37]. Whether or not this motif regulates the sorting and trafficking of Shank3 in vivo is an interesting question for further investigation. Third, the functional diversity of Shank3 isoforms is supported by the finding that Shank3 isoforms display different subcellular localization and differential effects on spine morphology. For example, the full length Shank3a increased the density of dendritic spines and PDS-95 puncta, but Shank3b and Shank3e have an opposite impact on dendritic spine development. The nuclear targeting of Shank3b in heterologous cells and neurons implicates that this isoform probably possesses a function other than as a scaffolding protein at the PSD as described to date. In addition, the temporally- and regionally-specific expression of Shank3 isoforms also supports the concept that different isoforms have different functions. Altogether, our data strongly support a notion that different Shank3 isoforms contribute differentially to synaptic function. Follow-up studies are warranted to determine the distinct role for each isoform in synaptic development and function.

\section{The complexity of Shank3 and the specification of synapses} Although the phenomena of alternative splicing and multiple promoters are commonly described in both neuronal and non-neuronal genes, the degree of the complexity described for Shank3 is somewhat unusual. A similar level or even more complexity has been described for genes such as Neurexin family proteins and Brain Derived Neurotrophic Factor [38,39]. The exact number of Shank3 mRNAs and protein isoforms is not known. Whether all mRNA isoforms are translated into proteins cannot be easily determined. Given the tissue-/cell-type and developmental-stage specific promoter usage and alternative splicing, the number of Shank3 isoforms could be very substantial and possibly reach to more than a hundred. The interesting question is whether there is a biological purpose underlying such complexity as has been observed for Shank3. Humans have billions of neurons and a trillion synapses but a relatively small number of genes in a genome (approximately 20,000). We have a limited understanding of what contributes to the diversity of synapses, and the current methods to classify different types of synapses are extremely simplified. From revealing the complexity of Shank3 and other synaptic proteins, one plausible hypothesis is that the myriad isoforms of Shank3 and other synaptic proteins are destined to contribute to the diversity or specification of types of synapses. One could speculate that the different isoforms of Shank3 may localize differentially in the nano-structure of the PSD, such as central versus peripheral sites in the PSD of the same synapse, or different isoforms of Shank3 are at different excitatory synapses in a given pyramidal neuron. In addition, some protein isoforms may be present only when the neurons are stimulated with certain types of neural activity that lead to local protein translation for specific Shank3 mRNA isoforms. To examine these possibilities, high resolution cellular imaging at single synapses is required and isoform-specific antibodies will be helpful to assist these analyses.

\section{The complex Shank3 transcriptional regulation and phenotypic heterogeneity of Shank3 mutant mice and SHANK3 causing ASD}

Considerable clinical heterogeneity in ASD has been well documented [40-42], although the cause underlying this heterogeneity remains largely unknown. Molecular heterogeneity due to the number of genes has been hypothesized to be one of the logical explanations $[43,44]$, and has been supported by the findings of whole exome or whole genome sequencing of ASD cases [45-48]. However, in the case of SHANK3 causing ASD, considerable heterogeneity is also observed among the cases with different mutations within the SHANK3 gene [8]. We have previously shown 
that human SHANK3 also displayed a similar pattern of promoter usage and alternative splicing [25]. With the knowledge of the complexity of Shank3 transcriptional regulation reported here, the clinical heterogeneity of SHANK3 causing ASD could be predicted to result from the disruption of different sets of SHANK3 isoforms due to the location of the mutation within the coding exons of SHANK3. This prediction has been supported by Shank3isoform mutant mouse models, in which phenotypic diversity was demonstrated among mutant mice with disruption of different isoforms [16-20]. A striking example is that disruption of Shank3a to Shank3c results in skin lesion/ increased self-grooming phenotype, but this phenotype is absent in Shank3a to Shank3b deficient mice, implicating the unique role of Shank3c in the development of selfinduced skin lesions. Although genetic background and environmental factors may also contribute to the phenotypic heterogeneity in SHANK3 causing ASD and Shank3 mutant mice, our analysis of Shank3 isoforms provides a framework at the molecular level to understand the question of phenotypic heterogeneity. A head-to-head comparison between different Shank3 mutant mice in the same genetic background and in vivo analysis of the function of each Shank3 isoform will yield insights into the mechanism underlying phenotypic heterogeneity in SHANK3 causing ASD.

\section{Conclusions}

In summary, we showed a complex transcriptional regulation of Shank3 in mouse brain that resulted in diverse Shank3 isoforms. The regional, developmental, activitydependent, and epigenetic modulation of isoform-specific expression and alternative splicing of Shank3 suggest a different function for each Shank3 isoform. It is predicted that the SHANK3 defects in reported ASD patients and Shank3 mutant mice are isoform-specific. Our study then provides a molecular framework to dissect clinical heterogeneity of SHANK3 causing human disorders and provide insight to better understand the molecular basis underlying the clinical heterogeneity of ASD in general. In addition, these findings are critically important to interpret the difference between different lines of Shank3 mutant mice and formulate the plan to further analyze these mutant mice to elucidate the contribution of Shank3 to the pathophysiology of ASD.

\section{Additional files}

Additional file 1: Table S1. List of Shank3 primers used in this study.

Additional file 2: Figure S1. Brain-specific expression of Shank3 intragenic promoters. (A) Shank3 gene structure. Intragenic promoters are shown as black arrows. Exons in red are alternatively spliced exons. In lower panel, positions of primers for Shank3 isoforms and splice variants used in this study are indicated. Note that splicing forward primer (in red) for E18S is specific for promoter 5. (B) The presence of multiple intragenic promoters supported by in silico data from ENCODE project using mouse mm10 genome assembly (http://genomebrowser.wustl.edu/). The CHIP sequence data using antibodies against RNA polymerase II (Pol II) and trimethylated lysine 4 of histone 3 (H3K4me3), two landmarks for active promoters, displayed several corresponding peaks (blue rectangular, dash line indicates a weak promoter) near Shank3 promoters (arrows below Shank3 gene) in brain tissues but not in heart and kidney, indicating these intragenic promoters are brain specific. (C) Brain specific expression of Shank3 isoforms from intragenic promoters. Left panel: Western blot analysis using a Shank3 antibody against C-terminus of SHANK3 (sc-30193, Santa Cruz, CA, USA) revealed multiple bands across different tissues. The bands with predicted size of Shank3c, 3d, and 3e are observed in cerebral cortex and cerebellum but not in heart, liver, and kidney. Shank3b is not detectable because it does not contain the C-terminal sequence of Shank3 protein. This result supports that the intragenic promoters are brain-specific. Right panel: Ponceau $\mathbf{S}$ staining of the PVDF membrane on the left panel to show that an equal amount of protein $(30 \mu \mathrm{g})$ was loaded to each lane. Note there is variation of endogenous protein composition across different tissues.

Additional file 3: Figure S2. Extensive splicing of Shank3 mRNAs. (A-B) Shank3 exons 10-12 spliced (E10-12S) variants. At least five different products of E10-12S are identified by RT-PCR (A) and the sequences of E10-12S variants were illustrated (B). Arrows indicate the position of primers. I: no splicing. II: exon 11 partially spliced out. III: exon 11 spliced out. IV: exons 11 to 12 spliced out. V: exons 10 to 12 spliced out. Note that regular PCR reactions yield mostly spliced variants as the full-length of this sequence without alternative splicing can only be amplified in GC-rich buffer due to the extremely high GC percentage (79\%) in exon 11 (see Materials and methods). (C-D) Shank3e spliced variants (E18S). Different sets of primers yielded various PCR products (C): left panel with primers 1 and 2, right panel with primers 1 and 3. The forward primer 1 is specific for Shank3e isoforms from promoter 5. Gene structure of full-length Shank3e and its spliced variants are illustrated in (D), with arrows showing the position for primers. I: no splicing. II: exon 18 spliced out. III: exons 18, 21, and 22 (partial) spliced out. IV: exons 18 to 21 and 22 (partial) spliced out. E-F, Splicing variants of Shank3 exon 21 and exon 22 (E21-22S). The PCR products are shown in (E), with left panel using primers 2 and 3, right panel using primers 1 and 3. Gene structure of exons 19-22 and its splicing variants were illustrated in $(\mathbf{F})$, with primers labeled as arrows. I: no splicing. II: exon 22 partially spliced out. III: exon 21 spliced out. IV: exon 21 and exon 22 (partial) spliced out. Gene bank accession numbers are shown in red for novel splicing variants identified by the current study. Accession numbers in black are splicing variants identified in the previous study by Wang et al. [18].

Additional file 4: Figure S3. Differential expression and alternative splicing of Shank3 isoforms in neurons and astrocytes. mRNAs from cultured hippocampal neurons and astrocytes were analyzed by RT-PCR. All major isoforms of Shank3 mRNAs were expressed abundantly in neurons as expected. Shank3a, 3c, 3d, 3e, and $3 e-1$ were low but readily detectable in astrocytes. Alternative splicing of exon 18 was mutually exclusive between cell types, with exon18 inclusion (E18S I) in neurons and exon18 exclusion (E18S II) in astrocytes. Similarly, the E18S III variant was exclusively observed in neurons while E18S IV was only found in astrocytes. N, neuron. A, astrocyte.

Additional file 5: Figure S4. Differentiated cellular distribution of Shank3 isoforms. Shank3 isoforms tagged with GFP (green) were expressed in COS-7 cells (A) or primary hippocampal neurons (B). Cells were co-stained with 4',6-diamidino-2-phenylindole (DAPI) to label the nuclei (blue). PSD-95 antibody was employed to distinguish hippocampal neurons. Note that Shank3b localizes in nuclei in both COS-7 cells and hippocampal neurons. Shank3 E22: EGFP-Shank3 exon 22 that only encodes SAM domain. Scale bar: $10 \mu \mathrm{m}$.

Additional file 6: Figure S5. Shank3 isoforms are not localized in inhibitory synapses. Shank3 isoforms tagged with GFP (green) were expressed in primary hippocampal neurons and co-stained with an inhibitory post-synaptic marker Gephyrin (red). Note that there is no overlapping of Gephyrin with Shank3 isoforms. Scale bar: $10 \mu \mathrm{m}$.

\section{Abbreviations}

ANK: Ankyrin repeat; ASD: Autism spectrum disorder; HDAC: Histone deacetylase; mGluR: Metabotropic glutamate receptor; NMDAR: N-methyl-D-aspartate 
receptor; ORF: Open reading frame; PSD: Postsynaptic density; PDZ: PSD-95/Discs large/ZO-1; q-PCR: Quantitative real-time polymerase chain reaction; SAM: Sterile alpha motif; SH3: Src homology 3; TSA: Trichostatin A.

\section{Competing interests}

The authors declare that they have no competing interests.

\section{Authors' contributions}

XW: Conception and design, data collection and analysis, manuscript writing, critical revision, and final approval of the manuscript. QX: Data collection and analysis, manuscript writing, and final approval of the manuscript. ALB: Data collection, manuscript writing and editing, critical revision, and final approval of the manuscript. YL: Data collection, manuscript writing, and final approval of the manuscript. YHJ: Conception and design, financial support, manuscript writing, and final approval of the manuscript. All authors read and approved the final manuscript.

\section{Acknowledgements}

We thank Shengli Zhao and Tingting Wang for generous gifts of EGFP plasmids. We thank Xinyu Cao for technical assistance. XW is supported by a postdoctoral fellowship from Phelan-McDermid Syndrome Foundation. QX is supported by a grant from Natural Science Foundation of China, NSFC (No. 81371270). ALB is a pre-doctoral fellow supported by Ruth K. Broad Foundation. YHJ is supported by an Autism Speaks grant, Ruth K. Broad Foundation, and National Institutes of Health grant R01MH098114-01.

\section{Author details}

'Division of Medical Genetics, Department of Pediatrics, Duke University School of Medicine, 27710 Durham, NC, USA. ${ }^{2}$ Department of Neurobiology, Duke University School of Medicine, 27710 Durham, NC, USA. ${ }^{3}$ Department of Child Health Care, Children's Hospital of Fudan University, 201102 Shanghai, China

Received: 24 January 2014 Accepted: 13 March 2014 Published: 25 April 2014

\section{References}

1. Sheng M, Kim E: The Shank family of scaffold proteins. J Cell Sci 2000, 113(Pt 11):1851-1856.

2. Ehlers MD: Synapse structure: glutamate receptors connected by the shanks. Curr Biol 1999, 9:R848-R850.

3. Grabrucker AM, Schmeisser MJ, Schoen M, Boeckers TM: Postsynaptic ProSAP/Shank scaffolds in the cross-hair of synaptopathies. Trends Cell Biol 2011, 21:594-603.

4. Tu JC, Xiao B, Naisbitt S, Yuan JP, Petralia RS, Brakeman P, Doan A, Aakalu VK, Lanahan AA, Sheng M, Worley PF: Coupling of $\mathrm{mGluR} /$ homer and PSD-95 complexes by the Shank family of postsynaptic density proteins. Neuron 1999, 23:583-592.

5. Naisbitt S, Kim E, Tu JC, Xiao B, Sala C, Valtschanoff J, Weinberg RJ, Worley $P F$, Sheng M: Shank, a novel family of postsynaptic density proteins that binds to the NMDA receptor/PSD-95/GKAP complex and cortactin. Neuron 1999, 23:569-582.

6. Uchino $S$, Wada H, Honda $S$, Nakamura $Y$, Ondo $Y$, Uchiyama T, Tsutsumi M, Suzuki E, Hirasawa T, Kohsaka S: Direct interaction of post-synaptic density-95/Dlg/ZO-1 domain-containing synaptic molecule Shank3 with GluR1 alpha-amino-3-hydroxy-5-methyl-4-isoxazole propionic acid receptor. J Neurochem 2006, 97:1203-1214.

7. Verpelli C, Dvoretskova E, Vicidomini C, Rossi F, Chiappalone M, Schoen M, Di Stefano B, Mantegazza R, Broccoli V, Bockers TM, Dityatev A, Sala C: Importance of Shank3 protein in regulating metabotropic glutamate receptor 5 (mGluR5) expression and signaling at synapses. J Biol Chem 2011, 286:34839-34850.

8. Jiang YH, Ehlers MD: Modeling autism by SHANK gene mutations in mice. Neuron 2013, 78:8-27.

9. Wilson HL, Wong AC, Shaw SR, Tse WY, Stapleton GA, Phelan MC, Hu S, Marshall J, MCDermid HE: Molecular characterisation of the 22q13 deletion syndrome supports the role of haploinsufficiency of SHANK3/PROSAP2 in the major neurological symptoms. J Med Genet 2003, 40:575-584.

10. Hamdan FF, Gauthier J, Araki Y, Lin DT, Yoshizawa Y, Higashi K, Park AR, Spiegelman D, Dobrzeniecka S, Piton A, Tomitori H, Daoud H, Massicotte C, Henrion E, Diallo O, S2D Group, Shekarabi M, Marineau C, Shevell M,
Maranda B, Mitchell G, Nadeau A, D'Anjou G, Vanasse M, Srour M, Lafrenière $R G$, Drapeau P, Lacaille JC, Kim E, Lee JR, et al: Excess of de novo deleterious mutations in genes associated with glutamatergic systems in nonsyndromic intellectual disability. Am J Hum Genet 2011, 88:306-316.

11. Moessner R, Marshall CR, Sutcliffe JS, Skaug J, Pinto D, Vincent J, Zwaigenbaum L, Fernandez B, Roberts W, Szatmari P, Scherer SW: Contribution of SHANK3 mutations to autism spectrum disorder. Am J Hum Genet 2007, 81:1289-1297.

12. Durand CM, Betancur C, Boeckers TM, Bockmann J, Chaste P, Fauchereau F, Nygren G, Rastam M, Gillberg IC, Anckarsater H, Sponheim E, GoubranBotros H, Delorme R, Chabane N, Mouren-Simeoni MC, de Mas P, Bieth E, Rogé B, Héron D, Burglen L, Gillberg C, Leboyer M, Bourgeron T: Mutations in the gene encoding the synaptic scaffolding protein SHANK3 are associated with autism spectrum disorders. Nat Genet 2007, 39:25-27.

13. Schaaf CP, Sabo A, Sakai Y, Crosby J, Muzny D, Hawes A, Lewis L, Akbar H, Varghese R, Boerwinkle E, Gibbs RA, Zoghbi HY: Oligogenic heterozygosity in individuals with high-functioning autism spectrum disorder. Hum Mol Genet 2011, 20(17):3366-3375.

14. Waga C, Okamoto N, Ondo Y, Fukumura-Kato R, Goto Y, Kohsaka S, Uchino S: Novel variants of the SHANK3 gene in Japanese autistic patients with severe delayed speech development. Psychiatr Genet 2011, 21:208-211.

15. Gauthier J, Champagne N, Lafreniere RG, Xiong L, Spiegelman D, Brustein E, Lapointe M, Peng H, Cote M, Noreau A, Hamdan FF, Addington AM, Rapoport JL, Delisi LE, Krebs MO, Joober R, Fathalli F, Mouaffak F, Haghighi AP, Néri C, Dubé MP, Samuels ME, Marineau C, Stone EA, Awadalla P, Barker PA, Carbonetto S, Drapeau P, Rouleau GA, S2D Team: De novo mutations in the gene encoding the synaptic scaffolding protein SHANK3 in patients ascertained for schizophrenia. Proc Natl Acad Sci U S A 2010, 107:7863-7868

16. Bozdagi O, Sakurai T, Papapetrou D, Wang X, Dickstein DL, Takahashi N, Kajiwara Y, Yang M, Katz AM, Scattoni ML, Harris MJ, Saxena R, Silverman JL, Crawley JN, Zhou Q, Hof PR, Buxbaum JD: Haploinsufficiency of the autism-associated Shank3 gene leads to deficits in synaptic function, social interaction, and social communication. Molecular Autism 2010, 1:15.

17. Peca J, Feliciano C, Ting JT, Wang W, Wells MF, Venkatraman TN, Lascola CD, Fu Z, Feng G: Shank3 mutant mice display autistic-like behaviours and striatal dysfunction. Nature 2011, 472:437-442.

18. Wang X, McCoy PA, Rodriguiz RM, Pan Y, Je HS, Roberts AC, Kim CJ, Berrios J, Colvin JS, Bousquet-Moore D, Lorenzo I, Wu G, Weinberg RJ, Ehlers MD, Philpot BD, Beaudet AL, Wetsel WC, Jiang YH: Synaptic dysfunction and abnormal behaviors in mice lacking major isoforms of Shank3. Hum Mol Genet 2011, 20:3093-3108.

19. Schmeisser MJ, Ey E, Wegener S, Bockmann J, Stempel AV, Kuebler A, Janssen AL, Udvardi PT, Shiban E, Spilker C, Balschun D, Skryabin BV, Dieck S, Smalla KH, Montag D, Leblond CS, Faure P, Torquet N, Le Sourd AM, Toro R, Grabrucker AM, Shoichet SA, Schmitz D, Kreutz MR, Bourgeron T, Gundelfinger ED, Boeckers TM: Autistic-like behaviours and hyperactivity in mice lacking ProSAP1/Shank2. Nature 2012, 486:256-260.

20. Kouser M, Speed HE, Dewey CM, Reimers JM, Widman A, Gupta N, Liu S, Jaramillo TC, Bangash M, Xiao B, Worley PF, Powell CM: Loss of predominant shank3 isoforms results in hippocampus-dependent impairments in behavior and synaptic transmission. J Neurosci 2013, 33:18448-18468.

21. Lim S, Naisbitt S, Yoon J, Hwang Jl, Suh PG, Sheng M, Kim E: Characterization of the Shank family of synaptic proteins. Multiple genes, alternative splicing, and differential expression in brain and development. J Biol Chem 1999, 274:29510-29518.

22. Leblond CS, Heinrich J, Delorme R, Proepper C, Betancur C, Huguet G, Konyukh M, Chaste P, Ey E, Rastam M, Anckarsäter H, Nygren G, Gillberg IC, Melke J, Toro R, Regnault B, Fauchereau F, Mercati O, Lemière N, Skuse D, Poot M, Holt R, Monaco AP, Järvelä I, Kantojärvi K, Vanhala R, Curran S, Collier DA, Bolton P, Chiocchetti A, et al: Genetic and functional analyses of SHANK2 mutations suggest a multiple hit model of autism spectrum disorders. PLoS Genet 2012, 8:e1002521.

23. Maunakea AK, Nagarajan RP, Bilenky M, Ballinger TJ, D'Souza C, Fouse SD, Johnson BE, Hong C, Nielsen C, Zhao Y, Turecki G, Delaney A, Varhol R, Thiessen N, Shchors K, Heine VM, Rowitch DH, Xing X, Fiore C, SchillebeeckX M, Jones SJ, Haussler D, Marra MA, Hirst M, Wang T, Costello JF: Conserved role of intragenic DNA methylation in regulating alternative promoters. Nature 2010, 466:253-257.

24. Waga C, Asano H, Sanagi T, Suzuki E, Nakamura Y, Tsuchiya A, Itoh M, Goto YI, Kohsaka S, Uchino S: Identification of two novel Shank3 transcripts in the developing mouse neocortex. J Neurochem 2014, 128(2):280-293. 
25. Zhu L, Wang $X$, Li XL, Towers A, Cao X, Wang $P$, Bowman $R$, Yang $H$, Goldstein J, Li YJ, Jiang YH: Epigenetic dysregulation of SHANK3 in brain tissues from individuals with autism spectrum disorders. Hum Mol Genet 2014, 23(6):1563-1783.

26. Wang $X$, Bey AL, Chung L, Krystal AD, Jiang YH: Therapeutic approaches for shankopathies. Dev Neurobiol 2014, 74:123-135.

27. Kim HJ, Magrane J: Isolation and culture of neurons and astrocytes from the mouse brain cortex. Methods Mol Biol 2011, 793:63-75.

28. Schneider CA, Rasband WS, Eliceiri KW: NIH Image to ImageJ: 25 years of image analysis. Nat Methods 2012, 9:671-675.

29. Wang XM, Li J, Feng XC, Wang Q, Guan DY, Shen ZH: Involvement of the role of Chk1 in lithium-induced G2/M phase cell cycle arrest in hepatocellular carcinoma cells. J Cell Biochem 2008, 104:1181-1191.

30. Bockers TM, Mameza MG, Kreutz MR, Bockmann J, Weise C, Buck F, Richter D, Gundelfinger ED, Kreienkamp HJ: Synaptic scaffolding proteins in rat brain. Ankyrin repeats of the multidomain Shank protein family interact with the cytoskeletal protein alpha-fodrin. J Biol Chem 2001, 276:40104-40112.

31. Ehlers MD: Activity level controls postsynaptic composition and signaling via the ubiquitin-proteasome system. Nat Neurosci 2003, 6:231-242.

32. Flavell SW, Greenberg ME: Signaling mechanisms linking neuronal activity to gene expression and plasticity of the nervous system. Annu Rev Neurosci 2008, 31:563-590.

33. Fischer A, Sananbenesi F, Mungenast A, Tsai LH: Targeting the correct HDAC(s) to treat cognitive disorders. Trends Pharmacol Sci 2010, 31:605-617.

34. Schor IE, Rascovan N, Pelisch F, Allo M, Kornblihtt AR: Neuronal cell depolarization induces intragenic chromatin modifications affecting NCAM alternative splicing. Proc Natl Acad Sci U S A 2009, 106:4325-4330

35. Beri S, Tonna N, Menozzi G, Bonaglia MC, Sala C, Giorda R: DNA methylation regulates tissue-specific expression of Shank3. J Neurochem 2007, 101:1380-1391.

36. Lim S, Sala C, Yoon J, Park S, Kuroda S, Sheng M, Kim E: Sharpin, a novel postsynaptic density protein that directly interacts with the shank family of proteins. Mol Cell Neurosci 2001, 17:385-397.

37. Scott DB, Blanpied TA, Swanson GT, Zhang C, Ehlers MD: An NMDA receptor $E R$ retention signal regulated by phosphorylation and alternative splicing. J Neurosci 2001, 21:3063-3072.

38. Missler M, Sudhof TC: Neurexins: three genes and 1001 products. Trends Genet 1998, 14:20-26.

39. Aid T, Kazantseva A, Piirsoo M, Palm K, Timmusk T: Mouse and rat BDNF gene structure and expression revisited. J Neurosci Res 2007, 85:525-535.

40. Lenroot RK, Yeung PK: Heterogeneity within autism spectrum disorders: what have We learned from neuroimaging studies? Front Hum Neurosci 2013, 7:733.

41. Rice $\mathrm{K}$, Moriuchi JM, Jones W, Klin A: Parsing heterogeneity in autism spectrum disorders: visual scanning of dynamic social scenes in school-aged children. J Am Acad Child Adolesc Psychiatry 2012, 51:238-248.

42. Betancur $C$ : Etiological heterogeneity in autism spectrum disorders: more than 100 genetic and genomic disorders and still counting. Brain Res 2011, 1380:42-77

43. Abrahams BS, Geschwind DH: Advances in autism genetics: on the threshold of a new neurobiology. Nat Rev Genet 2008, 9:341-355.

44. Szatmari P: Heterogeneity and the genetics of autism. J Psychiatry Neurosci 1999, 24:159-165.

45. Jiang YH, Yuen RK, Jin X, Wang M, Chen N, Wu X, Ju J, Mei J, Shi Y, He M, Wang G, Liang J, Wang Z, Cao D, Carter MT, Chrysler C, Drmic IE, Howe JL, Lau L, Marshall CR, Merico D, Nalpathamkalam T, Thiruvahindrapuram B, Thompson A, Uddin M, Walker S, Luo J, Anagnostou E, Zwaigenbaum L, Ring $\mathrm{RH}$, et al: Detection of clinically relevant genetic variants in autism spectrum disorder by whole-genome sequencing. Am J Hum Genet 2013, 93:249-263.

46. Sanders SJ, Murtha MT, Gupta AR, Murdoch JD, Raubeson MJ, Willsey AJ, Ercan-Sencicek AG, DiLullo NM, Parikshak NN, Stein JL, Walker MF, Ober GT, Teran NA, Song Y, El-Fishawy P, Murtha RC, Choi M, Overton JD, Bjornson RD, Carriero NJ, Meyer KA, Bilguvar K, Mane SM, Sestan N, Lifton RP, Günel M, Roeder K, Geschwind DH, Devlin B, State MW: De novo mutations revealed by whole-exome sequencing are strongly associated with autism. Nature 2012, 485:237-241.

47. Iossifov I, Ronemus M, Levy D, Wang Z, Hakker I, Rosenbaum J, Yamrom B, Lee YH, Narzisi G, Leotta A, Kendall J, Grabowska E, Ma B, Marks S, Rodgers
L, Stepansky A, Troge J, Andrews P, Bekritsky M, Pradhan K, Ghiban E, Kramer M, Parla J, Demeter R, Fulton LL, Fulton RS, Magrini VJ, Ye K, Darnell JC, Darnell RB, et al: De novo gene disruptions in children on the autistic spectrum. Neuron 2012, 74:285-299.

48. Neale BM, Kou Y, Liu L, Ma'ayan A, Samocha KE, Sabo A, Lin CF, Stevens C, Wang LS, Makarov V, Polak P, Yoon S, Maguire J, Crawford EL, Campbell NG, Geller ET, Valladares O, Schafer C, Liu H, Zhao T, Cai G, Lihm J, Dannenfelser R, Jabado O, Peralta Z, Nagaswamy U, Muzny D, Reid JG, Newsham I, Wu Y, et al: Patterns and rates of exonic de novo mutations in autism spectrum disorders. Nature 2012, 485:242-245.

doi:10.1186/2040-2392-5-30

Cite this article as: Wang et al:: Transcriptional and functional complexity of Shank3 provides a molecular framework to understand the phenotypic heterogeneity of SHANK3 causing autism and Shank3 mutant mice. Molecular Autism 2014 5:30.

\section{Submit your next manuscript to BioMed Central and take full advantage of:}

- Convenient online submission

- Thorough peer review

- No space constraints or color figure charges

- Immediate publication on acceptance

- Inclusion in PubMed, CAS, Scopus and Google Scholar

- Research which is freely available for redistribution

Submit your manuscript at www.biomedcentral.com/submit
C) Biomed Central 